\title{
$\beta$-Adrenergic Hyperresponsiveness in Compensated Hypothyroidism Associated with Down Syndrome
}

\author{
AMNON ZUNG, AYALA YARON, YEHUDITH ALTMAN, AND ZVI ZADIK \\ Pediatric Endocrine Unit, Kaplan Medical Center, affiliated with Hadassah Medical School, the Hebrew \\ University of Jerusalem, Rehovot 76100, Israel
}

\begin{tabular}{|c|c|}
\hline \multicolumn{2}{|c|}{ ABSTRACT } \\
\hline $\begin{array}{l}\text { Although compensated hypothyroidism (CH) is the most com- } \\
\text { mon thyroid impairment in Down syndrome (DS), its pathogenesis } \\
\text { remains elusive. Because primary gonadal failure is another DS- } \\
\text { associated endocrinopathy, we hypothesized that an impaired sig- } \\
\text { nal-transduction pathway shared by several organs may provide a } \\
\text { unifying explanation for both endocrinopathies. We assessed two } \\
\text { possible transduction-pathway components associated with CH in } \\
\text { DS: the G-protein adenylate-cyclase (AC) system and } \beta \text {-adrenergic } \\
\text { responsiveness, previously reported to be enhanced in DS fibro- } \\
\text { blasts. Twenty-one DS patients and } 14 \text { control subjects were stud- } \\
\text { ied. Peripheral mononuclear cells (PMCs) were incubated with } \\
\text { G-protein modulators [prostaglandin E1 (PGE1) and cholera toxin } \\
\text { (CTx)], an AC stimulator (forskolin), and a } \beta \text {-adrenergic agonist } \\
\text { (isoproterenol), and cAMP levels were determined. All participants } \\
\text { had normal plasma thyroid hormone levels, but } 11 \text { of the DS } \\
\text { patients had elevated TSH levels (hTSH), whereas in the } 10 \text { others, } \\
\text { they were normal (nTSH). cAMP levels in response to forskolin, } \\
\text { PGE1, and CTx were similar in all groups, whereas isoproterenol- } \\
\text { stimulated cAMP levels were significantly higher in the hTSH }\end{array}$ & $\begin{array}{l}\text { group than in the nTSH group and control subjects ( } 45 \pm 30 \text { versus } \\
22 \pm 9 \text { and } 21 \pm 9 \text { pmol } \cdot 10^{6} \text { cells }{ }^{-1} \cdot 10 \text { min }^{-1} \text {, respectively; } p= \\
0.02 \text { ). Four patients in the DS hTSH subgroup had impaired sexual } \\
\text { development. We found hyperresponsiveness of PMCs to a } \beta \text {-ad- } \\
\text { renergic agonist in a subgroup of DS patients with CH. If this } \\
\text { observation is applicable to the thyroid gland, then it may reflect a } \\
\text { mechanism in which negative effects on cell growth or responsive- } \\
\text { ness to TSH lead to CH. (Pediatr Res 58: 66-70, 2005) }\end{array}$ \\
\hline
\end{tabular}

Many studies over the past several decades have found an increased prevalence of various types of thyroid dysfunction in individuals with Down syndrome (DS), including congenital hypothyroidism (1) and thyroid autoimmune disease (2-5). However, the most prevalent thyroid disorder in this population is compensated hypothyroidism $(\mathrm{CH})$, characterized by mildly elevated TSH in the absence of signs of thyroid autoimmunity or clinical hypothyroidism. Its prevalence in DS has been reported to be in the range of 14 to $63 \%(3,5-8)$, but its cause remains elusive.

A decreased threshold in the pituitary gland to thyroxin in $\mathrm{CH}$, postulated in some studies $(3,5)$, seems unlikely because low-dose thyroxin treatment rapidly brings TSH to normal levels, suggesting that the thyroxin-TSH negative feedback mechanism is preserved (5). Others have suggested the pres-

Received March 31, 2004; accepted November 3, 2004

Correspondence: Amnon Zung, M.D., Pediatric Endocrinology Unit, Kaplan, Medical Center, Rehovot 76100, Israel; e-mail: amzung2@bezeqint.net.

DOI: 10.1203/01.PDR.0000156227.64424.20 ence of immunologically competent but biologically less active TSH $(3,9,10)$. However, this hypothesis was ruled out recently by Konings et al. (10), who postulated that $\mathrm{CH}$ derives from an impaired signal-transduction pathway involved in thyroid hormonogenesis. The presence of hypogonadism in some of our DS patients with $\mathrm{CH}$ led us to hypothesize that hypothyroidism is just one aspect of multiple hormone resistance in DS.

Gonadal impairment in DS is manifested by hypogonadism with subsequent elevation of LH and FSH levels but with normal levels of sex steroids, suggesting partial gonadal failure $(11,12)$. Several reports have elucidated partial gonadal resistance to gonadotropin stimulation in DS patients, manifested by blunted estradiol secretion in response to FSH stimulation (13) and suppressed testosterone secretion in response to human chorionic gonadotropin stimulation $(14,15)$ in women and men, respectively.

The combination of apparent multiple hormone resistance illustrated by these studies is reminiscent of the syndrome of pseudohypoparathyroidism (PHP). This syndrome is character- 
ized by variable expression of end-organ resistance to several hormones (PTH, TSH, LH, FSH, and ACTH) as a result of the decreased activity of Gs protein $(16,17)$. The Gs-mediated signal-transduction defect was studied in peripheral blood cells such as erythrocytes, platelets, and transformed lymphoblasts in patients with PHP (18-20). Taking PHP as a model, we measured the effect of several agents that are known to stimulate cAMP production either directly or via the Gs protein system in peripheral mononuclear cells (PMCs) that were obtained from patients with DS.

Another observation reported in DS in connection with the adenylate-cyclase (AC)-cAMP system two decades ago was enhanced cellular response to $\beta$-adrenergic stimulation. The enhanced cAMP production was reported in fibroblasts and platelets of individuals with DS $(21,22)$, but the clinical implications of that observation remained elusive. Using the same set of experiments, we also studied a possible association between this known phenomenon and the two endocrinopathies presented in DS, namely $\mathrm{CH}$ and gonadal dysfunction.

\section{METHODS}

Population. Twenty-one children and adolescents with DS (13 male; $8.4 \pm$ $6.0 \mathrm{y}$ of age; range: 1.5 to $19 \mathrm{y}$ ) were recruited for this study during planned visits to the Pediatric Neurology and Endocrinology units at Kaplan Medical Center. Fourteen age- and sex-matched healthy individuals (10 male; $8.2 \pm$ 5.2 y of age), who were referred to the Endocrinology Clinic for growth evaluation, served as control subjects. The control participants were found to have no endocrine or growth abnormalities. One of the control participants who had a height-SD score (SDS) $<-2$ received a diagnosis of familial short stature.

Growth parameters (height, weight, and body mass index) were obtained for each participant and expressed as SDS. Patients of both groups were examined by one of the authors (A.Z.), and special attention was paid to the thyroid gland examination. The study protocol was approved by the Ethics Committees of Kaplan Medical Center and the Israeli Ministry of Health, and informed consent was obtained from the parents of all participants.

Endocrinologic and immunologic studies. Peripheral blood samples were drawn from all participants as part of a routine check-up. Blood samples were checked for TSH, free T4, total T3, thyroid peroxidase autoantibodies, $\mathrm{LH}$, $\mathrm{FSH}$, and either testosterone or estradiol in male and female participants, respectively. All blood tests were performed in the chemistry and endocrinology laboratories at Kaplan Medical Center by Centaur analyzer. At the same time, an additional sample was drawn for PMC isolation and a study of cAMP levels.

PMC-derived cAMP measurements. PMCs were isolated from $5 \mathrm{~mL}$ of heparinized whole blood immediately after drawing by separation on Ficoll columns. After resuspension of the PMCs in PBS, cell count and viability were determined by microscopy with trypan blue. Only samples with $>90 \%$ viability were used. Samples of $1.0 \times 10^{6}$ cells each were exposed to 3-isobutyl1-methylxanthine, a phosphodiesterase inhibitor, at a final concentration of 1 $\mathrm{mM}$ for $15 \mathrm{~min}$ at $37^{\circ} \mathrm{C}$. PMCs then were incubated with the cAMPstimulating agents forskolin (at a final concentration of $200 \mu \mathrm{M}$ ), prostaglandin $\mathrm{E} 1(\mathrm{PGE} 1 ; 10 \mu \mathrm{M})$, or isoproterenol hydrochloride $(10 \mu \mathrm{M})$ for $10 \mathrm{~min}$ or with cholera toxin $(\mathrm{CTx} ; 1 \mu \mathrm{g} / \mathrm{mL}$ ) for $60 \mathrm{~min}$. Two additional samples were incubated with PBS only for 10 and 60 min, providing an unstimulated baseline. Incubation periods were terminated by boiling for $5 \mathrm{~min}$, and after centrifugation $(12,000 \times g$ for $10 \mathrm{~min})$, supernatants were kept at $-20^{\circ} \mathrm{C}$ until assay. All cAMP levels were measured in duplicate by a specific ELISA kit. Individual cAMP levels were expressed after subtracting the baseline cAMP values. The interassay coefficients of variance were 11 and $14 \%$ for low and high cAMP levels, respectively. All agents and the kit were purchased from Sigma Chemical Co.-Aldrich Co. (St. Louis, MO).

Statistical analysis. Between-group comparisons for various parameters were performed by $t$ test or ANOVA, as appropriate. Results are expressed as mean $\pm \mathrm{SD}$, with $p<0.05$ considered significant.

\section{RESULTS}

Clinical data. Clinical characteristics of all participants and their sex hormone and gonadotropin levels are presented in Table 1. Thyromegaly was not present in any of the DS patients or control subjects. The average age of the DS group was similar to that of the control group $(8.4 \pm 6.0$ versus $8.2 \pm$ $5.2 \mathrm{y}$, respectively), as were auxologic parameters such as weight SDS $(-0.5 \pm 1.5$ versus $0.7 \pm 2.7)$ and body mass index $(19.5 \pm 4.6$ versus $19.2 \pm 5.3)$. However, the average height SDS was significantly lower in the DS group than in control subjects $(-2.4 \pm 1.3$ versus $-0.8 \pm 1.6$, respectively; $p=0.003$ ).

Hormonal evaluation. Thyroid hormone levels in control and DS groups were statistically similar and within the normal range. Free T4 levels were $14.4 \pm 2.7$ versus $14.0 \pm 2.6$ $\mathrm{pmol} / \mathrm{L}(1.1 \pm 0.2$ versus $1.1 \pm 0.2 \mathrm{ng} / \mathrm{dL})$, and total T3 levels were $3.2 \pm 0.6$ versus $3.1 \pm 0.4 \mathrm{nmol} / \mathrm{L}(208 \pm 39$ versus $202 \pm 26 \mathrm{ng} / \mathrm{dL}$ ) in the DS and control groups, respectively. In contrast, average TSH level in the DS group was significantly higher than in the control group $(6.0 \pm 2.4$ versus $2.8 \pm 1.6$ $\mathrm{mIU} / \mathrm{L} ; p=0.001)$. The DS group was further divided into two subgroups that comprised 10 patients with normal TSH levels (nTSH) and 11 patients with elevated TSH levels (hTSH) for their age. The age-related normal ranges for thyroid hormone levels were based on comprehensive reference ranges, established using a Centaur analyzer (23). TSH levels in the nTSH group $(4.0 \pm 1.5 \mathrm{mIU} / \mathrm{L})$ were similar to those in the control group but significantly lower than corresponding levels in the hTSH group $(7.8 \pm 1.5 \mathrm{mIU} / \mathrm{L} ; p<0.001$ versus other groups). Thyroid autoantibodies were not detected in any of the participants in this study.

Sex steroids and gonadotropins were analyzed separately for prepubertal children (12 control and 14 DS subjects) and for participants during puberty (two control and seven DS subjects). Before puberty, LH levels in all participants were in the prepubertal range, but the control group had significantly higher LH levels than the DS patients $(0.5 \pm 0.5$ versus $0.3 \pm 0.1 \mathrm{IU} / \mathrm{L} ; p=0.022$ ). This difference, however, may not have any biologic significance. There was no difference in FSH levels between the groups before puberty $(1.3 \pm 1.0$ versus $1.7 \pm 2.0 \mathrm{IU} / \mathrm{L}$ in control and DS groups, respectively). Testosterone and estradiol levels among prepubertal boys and girls, respectively, were appropriate for their pubertal stage in both DS patients and control subjects, except in one girl who had DS and presented with an estradiol level of $99 \mathrm{pmol} / \mathrm{L}(27 \mathrm{pg} / \mathrm{mL})$, typical of early puberty (Table 1).

All sex steroid and gonadotropin levels in pubertal subjects with DS were significantly higher than corresponding levels in DS and control groups before puberty $[p<0.001$ for all comparisons; $5.3 \pm 1.3 \mathrm{IU} / \mathrm{L} \mathrm{LH}, 10.1 \pm 7.2 \mathrm{IU} / \mathrm{L}$ FSH, $378 \pm$ $189 \mathrm{pmol} / \mathrm{L}(103 \pm 51 \mathrm{pg} / \mathrm{mL})$ estradiol, and $7.0 \pm 3.8 \mathrm{nmol} / \mathrm{L}$ $(2.0 \pm 1.1 \mathrm{ng} / \mathrm{mL})$ testosterone]. No comparison was made to pubertal control subjects because of the small size of the subgroup $(n=2)$.

It is worth noting that two boys with DS (ages 1.8 and $2.9 \mathrm{y}$ ) had micropenis. In addition, two pubertal male patients with 
Table 1. Clinical characteristics and sex hormone and gonadotropin levels in control subjects and DS subgroups with normal and high TSH levels

\begin{tabular}{|c|c|c|c|c|c|c|}
\hline \multicolumn{7}{|c|}{ Control group } \\
\hline $\begin{array}{l}\text { Age } \\
\text { (y) }\end{array}$ & Sex & $\begin{array}{l}\text { Height } \\
\text { SDS }\end{array}$ & BMI & $\begin{array}{c}\mathrm{LH} \\
(\mathrm{IU} / \mathrm{L})\end{array}$ & $\begin{array}{c}\text { FSH } \\
\text { (IU/L) }\end{array}$ & $\begin{array}{l}\mathrm{E} 2(\mathrm{pmol} / \mathrm{L}) / \\
\mathrm{T}(\mathrm{nmol} / \mathrm{L})^{*}\end{array}$ \\
\hline 1.9 & $\mathrm{M}$ & 1.6 & 14.5 & $<0.3$ & 3.0 & $<0.3$ \\
\hline 3.6 & $\mathrm{~F}$ & -1.9 & 17.9 & $<0.3$ & 0.3 & $<37$ \\
\hline 4.5 & M & 0.9 & 15.6 & $<0.3$ & 0.4 & $<0.3$ \\
\hline 4.6 & M & -1.8 & 17.2 & $<0.3$ & 1.0 & $<0.3$ \\
\hline 5.1 & $\mathrm{~F}$ & -1.9 & 16.7 & $<0.3$ & 2.3 & $<37$ \\
\hline 5.3 & M & -2.3 & 17.3 & $<0.3$ & 0.6 & $<0.3$ \\
\hline 5.5 & M & 1.3 & 15.1 & $<0.3$ & 0.3 & $<0.3$ \\
\hline 6.8 & $\mathrm{~F}$ & 1.4 & 15.0 & $<0.3$ & 0.3 & $<37$ \\
\hline 7.0 & M & 1.2 & 14.1 & $<0.3$ & 1.9 & $<0.3$ \\
\hline 9.1 & M & -1.9 & 19.5 & $<0.3$ & 0.6 & $<0.3$ \\
\hline 12.8 & M & -1.7 & 24.1 & 1.2 & 2.0 & $<0.3$ \\
\hline 12.9 & M & -1.7 & 23.0 & 1.7 & 2.4 & $<0.3$ \\
\hline 16.9 & $\mathrm{~F}$ & -1.9 & 28.1 & 1.5 & 3.4 & 85 \\
\hline 18.7 & M & -1.8 & 30.6 & 4.4 & 4 & 40 \\
\hline \multicolumn{3}{|c|}{$8.2 \pm 5.2$} & \multicolumn{2}{|c|}{$19.2 \pm 5.3$} & & \\
\hline \multicolumn{7}{|c|}{ DS with nTSH } \\
\hline \multirow{2}{*}{$\begin{array}{l}\text { Age } \\
(\mathrm{y})\end{array}$} & \multirow[b]{2}{*}{ Sex } & \multirow{2}{*}{$\begin{array}{l}\text { Height } \\
\text { SDS }\end{array}$} & \multirow[b]{2}{*}{ BMI } & \multirow{2}{*}{$\begin{array}{c}\mathrm{LH} \\
(\mathrm{IU} / \mathrm{L})\end{array}$} & \multirow{2}{*}{$\begin{array}{c}\text { FSH } \\
(\mathrm{IU} / \mathrm{L})\end{array}$} & \multirow{2}{*}{$\begin{array}{l}\mathrm{E} 2(\mathrm{pmol} / \mathrm{L}) / \\
\mathrm{T}(\mathrm{nmol} / \mathrm{L})^{*}\end{array}$} \\
\hline & & & & & & \\
\hline 1.5 & M & -2.4 & 17.3 & $<0.3$ & 0.5 & $<0.3$ \\
\hline 3.2 & $\mathrm{~F}$ & -3.0 & 15.2 & 0.2 & 7.2 & 47 \\
\hline 3.4 & $\mathrm{~F}$ & -2.5 & 16.1 & $<0.3$ & 2.8 & 99 \\
\hline 3.6 & M & -1.7 & 15.3 & $<0.3$ & 0.3 & $<0.3$ \\
\hline 3.8 & M & -2.2 & 16.6 & $<0.3$ & 0.1 & $<0.3$ \\
\hline 5.3 & $\mathrm{M}$ & -0.6 & 15.4 & $<0.3$ & 3.6 & $<0.3$ \\
\hline 9.3 & M & -1.3 & 14.1 & $<0.3$ & 0.7 & $<0.3$ \\
\hline 14.8 & $\mathrm{~F}$ & -3.5 & 25.2 & 5.5 & 6.1 & 264 \\
\hline 16.3 & $\mathrm{~F}$ & -3.2 & 22.6 & 5.8 & 4.3 & 596 \\
\hline 17.2 & $\mathrm{~F}$ & -4.7 & 20.8 & 3.6 & 7.7 & 275 \\
\hline \multicolumn{2}{|c|}{$7.8 \pm 6.1$} & \pm 1.2 & $17.9 \pm$ & & & \\
\hline
\end{tabular}

DS with hTSH

\begin{tabular}{lcccccc}
\hline $\begin{array}{c}\text { Age } \\
\text { y) }\end{array}$ & Sex & $\begin{array}{c}\text { Height } \\
\text { SDS }\end{array}$ & BMI & $\begin{array}{c}\text { LH } \\
(\mathrm{IU} / \mathrm{L})\end{array}$ & $\begin{array}{c}\text { FSH } \\
(\mathrm{IU} / \mathrm{L})\end{array}$ & $\begin{array}{c}\mathrm{E} 2(\mathrm{pmol} / \mathrm{L}) / \\
\mathrm{T}(\mathrm{nmol} / \mathrm{L}) *\end{array}$ \\
\hline $1.8 \neq$ & $\mathrm{M}$ & -3.8 & 16.7 & $<0.3$ & 0.5 & $<0.3$ \\
$2.9 \neq$ & $\mathrm{M}$ & -1.0 & 17.2 & $<0.3$ & 0.1 & $<0.3$ \\
3.8 & $\mathrm{~F}$ & -0.7 & 19.5 & $<0.3$ & 2.7 & 64 \\
4.1 & $\mathrm{M}$ & -3.6 & 16.7 & $<0.3$ & 0.5 & $<0.3$ \\
5.3 & $\mathrm{~F}$ & -1.8 & 22.7 & $<0.3$ & 1.9 & $<37$ \\
6.3 & $\mathrm{~F}$ & -1.0 & 18.8 & $<0.3$ & 1.5 & $<37$ \\
12.5 & $\mathrm{M}$ & -2.3 & 20.5 & 0.6 & 1.8 & 2 \\
\hline 13.3 & $\mathrm{M}$ & -0.6 & 33.6 & 5.5 & 4.4 & 1.5 \\
13.6 & $\mathrm{M}$ & -2.6 & 21.1 & 4.4 & 8.2 & 10 \\
16.3 & $\mathrm{M} \S$ & -4.2 & 20.9 & 7.7 & 23.1 & 8.2 \\
19.0 & $\mathrm{M} \S$ & -4.0 & 24.1 & 4.7 & 17.1 & 8.4 \\
$9.0 \pm 6.1$ & $-2.3 \pm 1.4$ & $21.1 \pm 4.8$ & & & \\
\hline
\end{tabular}

Patients above the line in the table are prepubertal. E2, estradiol; T, testosterone.

* Plasma levels of E2 (in pmol/L) and T (in nmol/L) are presented for female and male individuals, respectively.

$\dagger$ Mean height SDS in control group is significantly higher than corresponding values in the DS subgroups by ANOVA $(p=0.007)$.

$\ddagger$ Patients with micropenis.

$\S$ Patients with elevated plasma FSH levels and reduced testicular volume.

DS (ages 16.3 and 19 y) had elevated FSH levels (23.1 and 17.1 IU/L) in association with reduced testicular volume (9 and $12 \mathrm{~mL}$ in the younger and older patients, respectively). All four patients belonged to the hTSH-DS subgroup (Table 1).
Stimulated PMC cAMP levels. PMC cAMP levels in the control group were similar to corresponding levels in the DS group when cells were stimulated with forskolin $(193 \pm 146$ versus $\left.264 \pm 225 \mathrm{pmol} \cdot 10^{6} \mathrm{cells}^{-1} \cdot 10 \mathrm{~min}^{-1}\right)$, PGE1 (67 \pm 25 versus $76 \pm 37 \mathrm{pmol} \cdot 10^{6}$ cells $\left.^{-1} \cdot 10 \mathrm{~min}^{-1}\right)$, CTx $(3.8 \pm$ 2.6 versus $7.4 \pm 15.8 \mathrm{pmol} \cdot 10^{6}$ cells $\left.^{-1} \cdot 10 \mathrm{~min}^{-1}\right)$, and isoproterenol $\left(21 \pm 9\right.$ versus $35 \pm 32 \mathrm{pmol} \cdot 10^{6}$ cells $^{-1} \cdot 10$ $\left.\min ^{-1}\right)$, respectively.

Similarly, there were no differences in stimulated cAMP levels in response to forskolin, PGE1, and CTx between the control group and DS subgroups stratified by TSH level (Table 2). Isoproterenol stimulation, however, yielded significantly higher cAMP levels in the hTSH group compared with nTSH and control groups ( $p=0.02$ by ANOVA; Table 2, Fig. 1$)$.

\section{DISCUSSION}

The presence of two different endocrinopathies in DS that are manifested by hyperthyrotropinemia and hypergonadotropinemia motivated us to evaluate a unifying hypothesis for both disturbances. Previous studies approached these problems separately, even though they may present simultaneously. Indeed, in our study, we found two patients who had DS and elevated levels of both TSH and FSH, with the latter being in the range seen in hypergonadotropic hypogonadism. Because elevated TSH and FSH levels can reflect end-organ resistance in different glands, we hypothesized a defect in signal transduction located beyond the receptor, one shared by the thyroid and the gonads. Similar reasoning led in 1980 to the recognition that patients with PHP type 1 bear a generalized defect in hormone-sensitive AC activity, mediated by a $50 \%$ deficiency in Gs, a component of the receptor-cyclase-coupling N-protein (16). This finding provided an explanation for the resistance of various glands to their activating hormones, working via AC stimulation. Unlike PHP, TSH elevation in DS is not associated with hypothyroidism but rather with $\mathrm{CH}$, in which thyroid hormones are in the normal range (5-8). Similarly, elevated gonadotropins in DS are associated with normal levels of sex steroids $(11,12)$, although some degree of gonadal dysfunction is common in this population. In women with DS, menarche may occur at a later age (24), and there is an increased frequency of anovulation or defects in luteal function $(25,26)$. In men with DS, the mean stretched penile length and testicular volume are below normal standards for adults $(11,12)$, with a negative correlation between testicular size and FSH levels (11). In our cohort of patients with DS, we found two adolescents with incomplete testicular maturation (in association with elevated FSH) and two with micropenis. On the basis of these data, it is conceivable that any end-organ resistance in DS is partial, rather than complete. We should emphasize that severe short stature, common to both subgroups of DS in our study (Table 1), is a cardinal characteristic of DS and is not associated with GH deficiency $(27,28)$ or any other endocrinopathy.

Following the PHP model, we measured PMC-derived cAMP in response to stimulation with forskolin, an AC activator, and CTx and PGE1, both activators of G-protein. All stimulants yielded a similar response in both DS subgroups (with normal and high TSH levels) and in the age- and 
Table 2. cAMP levels $\left(\mathrm{pmol} \cdot 10^{6}\right.$ cells $\left.\mathrm{s}^{-1} \cdot 10 \mathrm{~min}^{-1}\right)$ in DS subgroups with either $n T S H$ or hTSH compared with control group

\begin{tabular}{|c|c|c|c|c|}
\hline Stimulating agent & $\begin{array}{l}\text { cAMP levels in } \\
\text { control group } \\
\text { [TSH: } 2.8 \pm 1.6] \\
(n=14)\end{array}$ & $\begin{array}{l}\text { cAMP levels in } \\
\text { hTSH group } \\
\text { [TSH: } 7.8 \pm 1.5^{*} \text { ] } \\
(n=11)\end{array}$ & $\begin{array}{l}\text { cAMP levels in } \\
\text { nTSH group } \\
\text { [TSH: } 4.0 \pm 1.5] \\
(n=10)\end{array}$ & $p<0.001^{*}$ \\
\hline PGE1 $(10 \mu \mathrm{M})$ & $67 \pm 25$ & $82 \pm 40$ & $67 \pm 36$ & NS \\
\hline CTx $(1 \mu \mathrm{g} / \mathrm{ml})$ & $3.8 \pm 2.6$ & $10.1 \pm 21.3$ & $4.4 \pm 5.7$ & NS \\
\hline Isoproterenol $(10 \mu \mathrm{M})$ & $21 \pm 9$ & $45 \pm 30 *$ & $22 \pm 9$ & $0.02 *$ \\
\hline
\end{tabular}

For CTx, cAMP levels are expressed as pmol $\cdot 10^{6}$ cells $^{-1} \cdot 60 \mathrm{~min}^{-1}$. TSH levels are expressed in $\mathrm{mIU} / \mathrm{L}$.

* Statistically significant $v s$ other two groups by ANOVA.

sex-matched control groups; hence, our first hypothesis was not confirmed. However, we cannot rule out other defects in the signal-transduction pathway, such as increased activity of phosphodiesterase, which was neutralized in our study by the specific inhibitor 3-isobutyl-1-methylxanthine.

We further evaluated an alternative hypothesis, that alteration in the response to adrenergic stimulation, previously reported in fibroblasts $(21,22)$ and platelets $(22)$ from patients with DS, is causally related to the hyperthyrotropinemia in DS. Hyperresponsiveness to $\beta$-adrenergic agonists in human skin fibroblasts that were obtained from patients with DS was reported by McSwigan et al. (21) in 1981. The response in these cells was $\sim 3$ - to 10 -fold greater than in normal diploid fibroblasts and other aneusomic fibroblast strains. This exaggerated response was specific, because treatment of DS and control cells with PGE1 or CTx resulted in the same degree of cAMP accumulation (21). In a subsequent study, an enhanced physiologic response to catecholamine hormones was found in cultured DS-derived fibroblasts and platelets (22), a response that was specific to the adrenergic agonists. In both studies, the most potent stimulator of cAMP production in fibroblasts was isoproterenol, whereas epinephrine and norepinephrine had lesser effects, in declining order of potency.

In our study, an exaggerated response of PMCs to isoproterenol was demonstrated only in a subgroup of patients with DS and hyperthyrotropinemia. The response was $\sim 2$-fold greater than in the control group and in the nTSH subgroup of patients with DS. Similar to the previous studies in fibroblasts and platelets $(21,22)$, this altered response was specific to isoproterenol, because cAMP accumulation in response to forskolin, PGE1, and CTx stimulation was similar among the two DS subgroups and control subjects. Although thyroid function was not examined in the aforementioned studies $(21,22)$, the response to isoproterenol stimulation ranged widely in both $(\sim 250 \%$ difference between low and high stimulated cAMP levels). It therefore is possible that the populations studied contained patients with DS and both normal and high TSH levels. The difference in the range of cAMP responses between McSwigan et al. (21) and our study may be from the different cell types and methods used. Whereas we used freshly prepared PMCs, McSwigan et al. (21) used a fibroblast cell line that was maintained for many passages in culture and examined at confluence.

In a review of the DNA sequence of human chromosome 21 (29), the gene KCNJ6 encoding human G-protein-coupled inward rectifier potassium 2 (hiGIRK2) may be linked to the $\beta$-adrenergic transduction pathway. Indeed, isoproterenol was found to elicit GIRK currents in both rat cardiomyocyte- and Xenopus laevis oocyte-coexpressed $\beta$-adrenergic receptors (30).

The hyperresponsiveness to isoproterenol in different cells of patients with DS suggests a general phenomenon that may be shared by other organs, including the thyroid gland and gonads. Several studies have shown that increased cAMP production in response to $\beta$-adrenergic stimulation induces a negative effect on the growth of various thyroid cell lines. These studies may provide the link among $\beta$-adrenergic hyperresponsiveness, enhanced cAMP accumulation, and $\mathrm{CH}$ in DS.

In a study by Ohta et al. (31), cAMP inhibited the growth of some human thyroid carcinoma cell lines, as evaluated by reduced thymidine incorporation and cell number. The production of cAMP was regulated through $\beta$-adrenergic receptormediated pathways but not through TSH receptor-mediated ones. The high expression of $\beta$-adrenergic receptors rendered these cell lines sensitive to the growth-inhibition effect of cAMPstimulated adrenergic receptor agonists. It is interesting that the potency ranking among $\beta$-adrenergic agonists was identical to that previously found in fibroblasts from a DS population $(21,22)$, namely isoproterenol $>$ epinephrine $>$ norepinephrine. Studies in differentiated rat thyroid cells (FRTL) have shown that isoproterenol reduces these cells' growth (32) and partially inhibits TSH's ability to stimulate cAMP and DNA synthesis (33).

The mechanism by which isoproterenol inhibits thyroid cell growth, either directly or via cAMP stimulation, is unknown. However, treatment of 3T3-L1 adipose cells that express TSH receptors with isoproterenol for $4 \mathrm{~h}$ resulted in a cAMPmediated decrease in TSH receptor mRNA levels, with a maximum of $60 \%$ inhibition (34). We postulate that decreased TSH receptor mRNA levels may subsequently lead to reduced levels of the membrane TSH receptor and relative resistance to TSH. The clinical outcome of such a process would be $\mathrm{CH}$.

There are no reports of a negative effect of $\beta$-adrenergic agents on gonadal cells, although these agents (including isoproterenol) are capable of inducing cAMP production and steroidogenesis in ovarian cells $(35,36)$. Therefore, we cannot comment on a similar mechanism of cAMP-mediated reduced responsiveness to gonadotropins in the gonads as an explanation for partial gonadal failure in DS. However, the presence of impaired sexual maturation in four of the patients with DS and $\mathrm{CH}$ suggests a common mechanism for both endocrinopathies. 


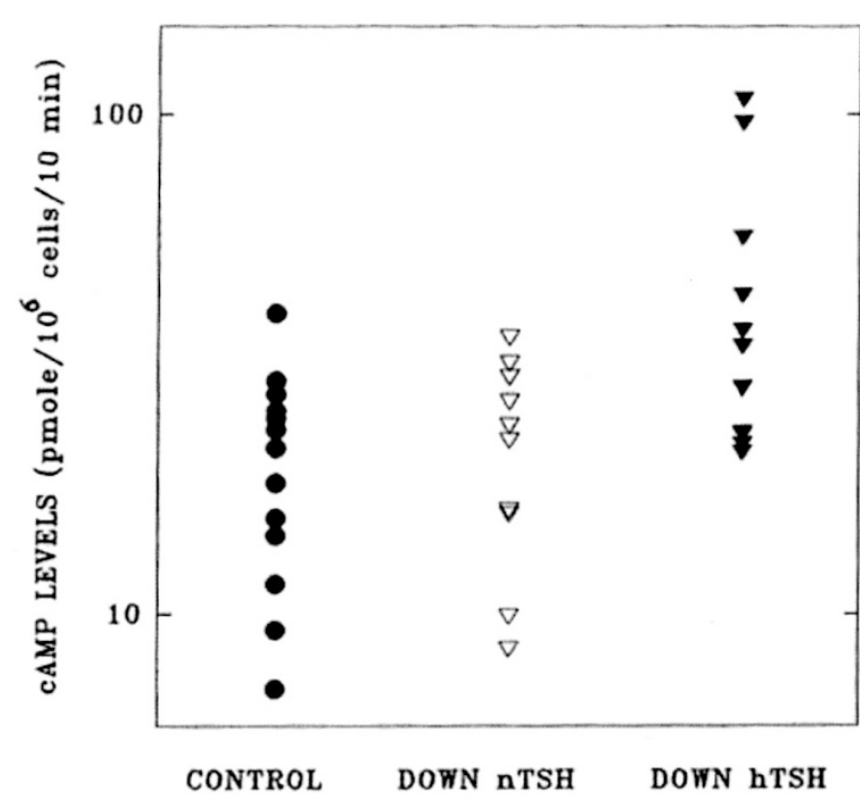

Figure 1. Isoproterenol-stimulated cAMP levels in control subjects $(n=14)$ and patients with DS and either normal TSH (nTSH; $n=10$ ) or elevated TSH (hTSH; $n=11$ ). CAMP levels in the hTSH group were significantly higher than those in the control and nTSH groups by ANOVA $(p=0.02)$. Data are represented on a logarithmic scale.

\section{CONCLUSION}

In summary, we found hyperresponsiveness (i.e. exaggerated cAMP production) to isoproterenol in PMCs from patients with DS and $\mathrm{CH}$. This effect was specific for isoproterenol and was not produced by other AC stimulators. Although it is conceivable that this effect, reported to date in PMCs (our study), fibroblasts $(21,22)$, and platelets (22), is a general one in DS, further study of the thyroid gland and gonads is required to confirm our hypothesis that increased cAMP accumulation in response to adrenergic stimulation is related to $\mathrm{CH}$ and gonadal impairment in DS.

\section{REFERENCES}

1. Fort P, Lifshitz F, Bellisario R, Davis J, Lanes R, Pugliese M, Richman R, Post EM, David R 1984 Abnormalities of thyroid function in infants with Down syndrome. J Pediatr 104:545-549

2. Loudon MM, Day RE, Duke EM 1985 Thyroid dysfunction in Down's syndrome. Arch Dis Child 60:1149-1951

3. Sharav T, Collins RM Jr, Baab PJ 1988 Growth studies in infants and children with Down's syndrome and elevated levels of thyrotropin. Am J Dis Child 142:1302-1306

4. Karlsson B, Gustafsson J, Hedov G, Ivarsson SA, Anneren G 1998 Thyroid dysfunction in Down's syndrome: relation to age and thyroid autoimmunity. Arch Dis Child 79:242-245

5. Gruneiro de Papendieck LG, Chiesa A, Bastida MG, Alonso G, Finkielstain G, Heinrich JJ 2002 Thyroid dysfunction and high thyroid stimulating hormone levels in children with Down's syndrome. J Pediatr Endocrinol Metab 15:1543-1548

6. Pueschel SM, Pezzullo JC 1985 Thyroid dysfunction in Down syndrome. Am J Dis Child 139:636-639

7. Cutler AT, Benezra-Obeiter R, Brink SJ 1986 Thyroid function in young children with Down syndrome. Am J Dis Child 140:479-483

8. Tuysuz B, Beker DB 2001 Thyroid dysfunction in children with Down's syndrome. Acta Paediatr 90:1389-1393

9. Sharav T, Landau H, Zadik Z, Einarson TR 1991 Age-related patterns of thyroidstimulating hormone response to thyrotropin-releasing hormone stimulation in Down syndrome. Am J Dis Child 145:172-175
10. Konings $\mathrm{CH}$, van Trotsenburg AS, Ris-Stalpers C, Vulsma T, Wiedijk BM, De Vijlder JJ 2001 Plasma thyrotropin bioactivity in Down's syndrome children with subclinical hypothyroidism. Eur J Endocrinol 144:1-4

11. Hasen J, Boyar RM, Shapiro LR 1980 Gonadal function in trisomy 21. Horm Res $12: 345-350$

12. Hsiang YH, Berkovitz GD, Bland GL, Migeon CJ, Warren AC 1987 Gonadal function in patients with Down syndrome. Am J Med Genet 27:449-458

13. Cento RM, Ragusa L, Proto C, Alberti A, Fiore G, Colabucci F, Lanzone A 1997 Ovarian sensitivity to follicle stimulating hormone is blunted in normo-ovulatory women with Down's syndrome. Hum Reprod 12:1709-1713

14. Sasagawa I, Nakada T, Hashimoto T, Ishigooka M, Izumiya K, Kubota Y, Tomaru M 1993 Hormone profile and contralateral testicular histology in Down's syndrome with unilateral testicular tumor. Arch Androl 30:93-98

15. Sasagawa I, Nakada T, Kubota Y, Ishigooka M, Hashimoto T, Sawamura T, Tateno T 1995 Ultrastructure of Leydig cells in Down's syndrome. Int Urol Nephrol 27:585-591

16. Farfel Z, Brickman AS, Kaslow HR, Brothers VM, Bourne HR 1980 Defect of receptor-cyclase coupling protein in pseudohypoparathyroidism. N Engl J Med 303:237-242

17. Spiegel AM, Shenker A, Weinstein LS 1992 Receptor-effector coupling by G proteins: implications for normal and abnormal signal transduction. Endocr Rev 13:536-565

18. Farfel Z, Bourne HR 1980 Deficient activity of receptor-cyclase coupling protein in platelets of patients with pseudohypoparathyroidism. J Clin Endocrinol Metab 51:1202-1204

19. Farfel Z, Abood ME, Brickman AS, Bourne HR 1982 Deficient activity of receptorcyclase coupling protein in transformed lymphoblasts of patients with pseudohypoparathyroidism type 1. J Clin Endocrinol Metab 55:113-117

20. Levine MA, Jap TS, Mauseth RS, Downs RW, Spiegel AM 1986 Activity of the stimulatory guanine nucleotide-binding protein is reduced in erythrocytes from patients with pseudohypoparathyroidism and pseudopseudohypoparathyroidism: biochemical, endocrine, and genetic analysis of Albright's hereditary osteodystrophy in six kindreds. J Clin Endocrinol Metab 62:497-502

21. McSwigan JD, Hanson DR, Lubiniecki A, Heston LL, Sheppard JR 1981 Down syndrome fibroblasts are hyperresponsive to $\beta$-adrenergic stimulation. Proc Natl Acad Sci USA 78:7670-7673

22. Sheppard JR, McSwigan JD, Wehner JM, White JG, Shows TB, Jakobs KH, Schultz G 1982 The adrenergic responsiveness of Down syndrome cells. Prog Clin Biol Res 97:307-325

23. Hubner U, Englisch C, Werkmann H, Butz H, Georgs T, Zabransky S, Herrmann W 2002 Continuous age-dependent reference ranges for thyroid hormones in neonates, infants, children and adolescents established using the ADVIA Centaur Analyzer. Clin Chem Lab Med 40:1040-1047

24. Bellone E, Tanganelli E, La Placa A, Daneri C 1980 Menarca e fisiopatologia mestruale nella sindrome di Down. Minerva Ginecol 32:579-588

25. Scola PS, Pueschel SM 1992 Menstrual cycles and basal body temperature curves in women with Down syndrome. Obstet Gynecol 79:91-94

26. Cento RM, Ragusa L, Proto C, Alberti A, Romano C, Boemi G, Colabucci F, Lanzone A 1996 Basal body temperature curves and endocrine pattern of menstrual cycles in Down syndrome. Gynecol Endocrinol 10:133-137

27. Anneren G, Sara VR, Hall K, Tuvemo T 1986 Growth and somatomedin responses to growth hormone in Down's syndrome. Arch Dis Child 61:48-52

28. Barreca A, Rasore Quartino A, Acutis MS, Ponzani P, Damonte G, Miani E, Balestra V, Giordano G, Minuto F 1994 Assessment of growth hormone insulin like growth factor-1 axis in Down syndrome. J Endocrinol Invest 17:431-436

29. The Chromosome 21 Mapping and Sequencing Consortium 2000 The DNA sequence of human chromosome 21. Nature 405:311-319

30. Mullner C, Vorobiov D, Bera AK, Uezono Y, Yakubovich D, Frohnwieser-Steinecker B, Dascal N, Schreibmayer W 2000 Heterologous facilitation of G protein-activated $\mathrm{K}(+)$ channels by beta-adrenergic stimulation via cAMP-dependent protein kinase. J Gen Physiol 115:547-558

31. Ohta K, Pang XP, Berg L, Hershman JM 1997 Growth inhibition of new human thyroid carcinoma cell lines by activation of adenylate cyclase through the $\beta$-adrenergic receptor. J Clin Endocrinol Metab 82:2633-2638

32. Endo T, Shimura H, Saito T, Onaya T 1990 Cloning of malignantly transformed rat thyroid (FRTL) cells with thyrotropin receptors and their growth inhibition by 3',5'-cyclic adenosine monophosphate. Endocrinology 126:1492-1497

33. Tsuzaki S, Cone RD, Fraizer AL, Moses AC 1991 The interaction of signal transduction pathways in FRTL5 thyroid follicular cells: studies with stable expression of $\beta 2$-adrenergic receptors. Endocrinology 128:1359-1368

34. Shimura H, Haraguchi K, Endo T, Onaya T 1997 Regulation of thyrotropin receptor gene expression in 3T3-L1 adipose cells is distinct from its regulation in FRTL-5 thyroid cells. Endocrinology 138:1483-1490

35. Suh BS, Amsterdam A 1990 Establishment of highly steroidogenic granulose cell lines by cotransfection with SV40 and Ha-ras oncogene: induction of steroidogenesis by cyclic adenosine 3 '-5'-monophosphate and its suppression by phorbol esther. Endocrinology 127:2489-2500

36. Gonzalez CB, Cantore ML, Passeron S 1994 Steroidogenesis in immature chicken ovary. Hormonal stimulation of adenylyl cyclase system by luteinizing hormone and beta-adrenergic agonists. Cell Biol Int 18:103-110 